\title{
IMPLEMENTASI DAN PEMBIASAAN KARAKTER KEPEDULIAN LINGKUNGAN DALAM PEMBELAJARAN PAI DI MAN YOGYAKARTA II
}

\author{
Noorrela Ariyunita \\ Universitas Islam Negeri Sunan kalijaga Yogyakarta \\ noorrelaa@gmail.com
}

\begin{abstract}
ABSTRAK
Penelitian ini merupakan penelitian kualitatif, dengan mengambil latar MAN Yogyakarta II sebagai tempat penelitian. Subyek penelitian ini adalah kepala sekolah, guru PAI, dan siswa MAN Yogyakarta II. Sedangkan obyek penelitiannya adalah penerapan nilai kepedulian lingkungan dalam pembelajaran PAI di MAN Yogyakarta II. Pengumpulan data dilakukan dengan mengadakan observasi, wawancara, dan dokumentasi. Penelitian ini menggunakan pendekatan fenomenologis. Metode berfikir dalam analisis data penelitian bersifat induktif dengan menghimpun dan menggabugkan kata-kata khusus menjadi kesatuan informasi serta digabungkan dengan teknik triangulasi data. Hasil penelitian menunjukkan: (1) Nilai kepedulian lingkungan akan masuk pada diri peserta didik dan akan menjadi nilai karakter apabila diajarkan secara terus menerus dan dikerjakan bersama-sama secara serentak dengan semua warga sekolah dan keluarga. Peran PAl dalam penerapan nilai peduli lingkungan juga sangat berpengaruh terhadap cara berfikir dan cara bersikap siswa di kehidupan sehari-hari diluar maupun didalam lingkungan sekolah. (2) faktor penghambat implementasi nilai kepedulian lingkungan adalah (a) waktu yang relativ singkat, (b) Perbedaan karakter siswa, (c) kurangnya pengawasan diluar sekolah. Sedangkan faktor pendukungnya adalah: (a) visi dan misi madrasah, (b) APeL (Agen Peduli Lingkungan), (c) Reward and Punishment, dan (e) kegiatan ekstrakurikuler.
\end{abstract}

Kata Kunci: karakter, kepedulian lingkungan, Pembelajaran PAI

\section{ABSTRACT}

This research is a qualitative research, with the setting of MAN Yogyakarta II as a research site. The subjects of this study were the principal, PAI teacher, and MAN Yogyakarta II students. While the object of research is the application of the value of environmental awareness in the learning of Islamic Education in MAN Yogyakarta II. Data collection is done by conducting observations, interviews, and documentation. This research uses a phenomenological approach. The method of thinking in the analysis of research data is inductive by gathering and combining special words into a unit of information and combined with data triangulation techniques. The results of the study show: (1) The value of environmental awareness will enter the learners and will become a character value if taught continuously 
and worked together simultaneously with all members of the school and family. The role of PAI in the application of the value of caring for the environment is also very influential on how students think and behave in daily life outside and within the school environment. (2) the inhibiting factors for the implementation of the value of environmental care are (a) relatively short time, (b) Differences in student character, (c) lack of supervision outside of school. While the supporting factors are: (a) madrasa vision and mission, (b) APeL (Agen Peduli Lingkungan as Environmental Care Agency), (c) Reward and Punishment, and (e) extracurricular activities.

Keywords: Character, Environmental care, PAl learning 


\section{PENDAHULUAN}

Salah satu tugas utama manusia di bumi adalah menjaga bumi beserta seluruh isinya agar tetap nyaman untuk kehidupan mendatang, karena seluruh alam raya diciptakan agar digunakan dan dimanfaatkan oleh manusia sebaik-baiknya sebagai sarana beribadah kepada Allah. Sebagai khalifah di bumi, manusia diamanatkan untuk menggunakan segala sumber daya alam secara baik, benar dan proporsional. Melalui akalnya, manusia dapat berinovasi dan berfikir kreatif untuk memanfaatkan sumber daya alam yang telah ada untuk kebutuhan bersama manusia yang lain dimuka bumi. Namun, jika manusia menggunakan semua sumber daya tersebut secara eksploratif, maka hal ini akan membahayakan manusia dan lingkungannya sendiri.

Agama sebagai ajaran yang ditetapkan Tuhan kepada manusia untuk mengontrol segala perbuatan manusia, pun tidak sedikit menyerukan kepada manusia untuk bersikap bijaksana kepada alam (Haidi Hajar Widagdo: 2012). Salah satu ajaran agama yang menyerukan kepada manusia untuk tidak berbuat sewenang-wenang terhadap alam adala Q.S AI A'raf ayat 56 yang artinya:

"Dan janganlah kamu membuat kerusakan di muka bumi, sesudah (Allah) memperbaikinya dan berdo'alah kepada Allah dengan rasa takut (tidak akan diterima) dan harapan (akan dikabulkan). Sesungguhnya rahmat Allah amat dekat kepada orang-orang yang berbuat baik." (Departemen Agama RI: 2012)

Ayat diatas merupakan sebuah larangan kepada manusia untuk tidak berbuat kerusakan kepada sesama manusia, maupun kepada makhluk hidup lainnya, termasuk juga kepada alam. Alam raya telah diciptakan Allah dalam keadaan baik, serasi, indah, harmonis, dan memenuhi segala kebutuhan makhluk. Allah juga memerintahkan manusia untuk memperbaikinya.

Salah satu bentuk perbaikan Allah adalah dengan mengutus manusia yang merupakan pemimpin di bumi. Pemimpin yang dimaksud adalah pemimpin yang memiliki sifat muhsin, yaitu siapa yang melihat dirinya pada posisi kebutuhan orang lain dan tidak melihat dirinya pada saat beribadah kepada Allah SWT (Quraish Shihab: 2004)

Namun pada kenyataannya, seiring perubahan manusia dari yang sebelumnya berpola fikir "primitif" berkembang menjadi pola pikir "modern", perilaku manusia pun berkembang atau lebih tepatnya bergeser dari yang sebelumnya mencintai, dan menghargai alam menjadi cenderung mengeksploitasi alam. Manusia modern (manusia yang menjadikan akal, ilmu dan teknologi sebagai acuan utama dalam 
kehidupan) telah menciptakan banyak kesenjangan (ketidakseimbangan) antara sumber daya dengan jumlah penduduk suatu wilayah atau daerah (Haidi Hajar Widagdo: 2012). Dengan banyaknya penduduk dimuka bumi, semakin banyak pula perbuatan-perbuatan manusia yang merusak bumi untuk memenuhi segala kebutuhan manusia, sehingga manusia tidak memiliki sikap kepedulian lingkungan.

Salah satu dari tujuh langkah yang ditawarkan oleh S. Husain Nasr dalam tulisan Ahmad Suhendra untuk memperbaiki krisis lingkungan adalah dengan mengupayakan pemahaman Islam akan alam lingkungan dan kemanusiaan merupakan suatu hubungan yang harus diformulasikan dan diekspresiakan dengan bahasa yang jelas, yang dapat dipahami oleh umat kontemporer (Ahmad Suhendra:2013) Dalam hal ini, salah satu cara untuk menanamkan pemahaman tentang pentingnya peduli kepada lingkungan adalah melalui pendidikan.

Pendidikan adalah usaha sadar dan terencana untuk mewujudkan suasana belajar dan proses pembelajaran agar peserta didik secara aktif mengembangkan potensi dirinya untuk memiliki kekuatan spiritual keagamaan, pengendalian diri, kepribadian, kecerdasan, akhlak mulia serta keterampilan yang diperlukan dirinya, masyarakat, bangsa dan negara (UU RI No 20 Tahun 2003).

MAN Yogyakarta II merupakan sekolah yang mendapatkan penghargaan Adiwiyata tahun 2014. Adiwiyata adalah program Kementrian Lingkungan Hidup dalam rangka mendorong terciptanya pengetahuan dan kesadaran sekolah dalam upaya pelestarian lingkungan hidup. Kajian lingkungan pada tahun 2012 menunjukkan bahwa masalah lingkungan yang mendesak untuk dipecahkan adalah pengelolaan sampah, penataan kantin bersih dan sehat serta penataan dan penghijauan lingkungan madrasah. Maka tema program Adiwiyata MAN Yogyakarta II tahun pertama adalah Green and Clean.

\section{Rumusan Masalah}

Pendidikan memiliki peran sentral dalam pengembangan dan pembiasaan karakter bagi peserta didik. Pendidikan karakter dapat berhasil jika diajarkan secara terus menerus dan akan mennjadi karakter jika semua lapisan sekolah mendukung pendidikan tersebut. Salah satu karakter yang penting dan harus dimiliki oleh peserta didik adalah karakter peduli lingkungan. Karakter Peduli lingkungan merpakan salah satu dari sikap sosial yang semestinya harus dimiiki dan menjadi kebiasaan bagi peserta didik. 
Karakter peduli lingkungan menjadi suatu karakter yang penting seiring dengan semakin rusaknya lingkungan hidup. Salah satu lembaga yang memiliki andil besar dalam mengembangkan karakter tersebut adalah lembaga pendidikan formal maupun non formal. Sebagai salah satu bentuk mnedukung pengembangan gerakan peduli lingkungan, pemerintah mulai memberikan apresiasi kepada sekolah yang mampu memberikan kontribusi nyata untuk mengembangkan karakter peduli lingkungan.

Oleh karena itu, perlu kiranya dilakukan penelitian mengenai penanaman atau implementasi karakter peduli lingkungan dalam pembelajaran, khususnya dalam pembelajaran Pendidikan Agama Islam.

\section{Tujuan Penelitian}

Adapun tujuan dilakukannya penelitian ini adalah untuk mengetahui bagaimana cara madrasah yang telah menerima penghargaan Adiwiyata Mandiri mengajarkan sikap atau karakter peduli lingkungan lewat pembelajaran Pendidikan Agama Islam (PAI), sebagai bentuk pemaknaan terhadap ajaran agama Islam dan juga kerja nyata untuk menciptakan generasi berkarakter di Indonesia.

\section{METODE PENELITIAN}

Penelitian ini termasuk dalam kategori penelitian lapangan (field research) yaitu penelitian yang pengumpulan datanya dilakukan dilapangan, seperti di lingkungan masyarakat dan lembaga pendidikan formal maupun informal (Hadari Nawawi:2007). Penelitian ini termasuk dalam penelitian kualitatif, yaitu penelitian yang bermaksud untuk memahami fenomena tetang apa yang dialami oleh subjek penelitian misalnya perilaku, persepsi, motivasi, tindakan, dll (lexy J. Moloeng: 2005). Pendekatan yang digunakan dalam penelitian ini adalah pendekatan fenomenologis. Fenomenologi merupakan sebuah pedekatan filosofis untuk menyelidiki pengalaman manusia.pendekata fenomenologi menuntun pada pemahaman perilaku manusia dari kerangka berfikir pelaku yang bersangkutan (Arif Furchan:1992).

Demi mendapatkan hasil penelitian yang valid tentunya diperlukan banyak data yang diperoleh melalui sumber data yang nantinya akan diolah dalam kajian penelitian. Sumber data adalah subjek dari mana data diperoleh (Suharsimi Arikuto:2006). Adapun sumber data primer sekaligus yang menjadi subyek penelitian dalam penelitian ini adalah Guru PAI, Kepala Sekolah dan beberapa siswa. Untuk menentukan siswa yang akan di wawancara, peneliti menggunakan metode random sampling karena pengambilan anggota sampel daripopulasi dilakukan secara acak tanpa memperhatikan strata yang ada dalam populasi itu (Sugiyono:2010). 


\section{Metode Pengumpulan Data}

Metode pengumpulan data yang digunakan dalam penelitian ini adalah metode observasi, wawancara dan dokumentasi langsung. Metode observasi merupakan suatu teknik atau cara mengumpulkan data dengan jalan mengadakan pengamatan terhadap kegiatan yang sedang berjalan langsung (Nana Syaodih:2010). Observasi yang dilakukan oleh peneliti adalah observasi nonpartisipan, dimana peneliti tidak ikut serta dalam kegiatan dan hanya berperan sebagai pengamat kegiatan.

Metode waancara merupakan suatu bentuk komunikasi verbal semacam percakapan yang bertujuan memperoleh informasi (S. Nasution: 2006). Metode wawancara yang akan digunakan adalah wawancara tidak terstruktur, yaitu wawancara yang bebas di mana peneliti tidak menggunakan pedoman wawancara yang telah tersusun secara sistematis dan lengkap untuk pengumpulan datanya (Sugiyono: 2010). Subyek dalam wawancara ini adalah guru PAI, kepala sekolah, dan peserta didik.

Metode dokumentasi adalah suatu teknik pengumpulan data dengan menghimpun dan menganalisis dokumen-dokumen, baik dokumen tertulis, gambar maupun elektronik (Nana Syaodih:2010). Dokumen yang dihimpun dipilih yang sesuai dengan tujuan dan fokus masalah. Analisis data menggunakan teknik trianggulasi untuk mendapatkan hasil yang sinkron antara hasil observasi lapangan, data dan wawancara.

\section{PEMBAHASAN}

Nilai merupakan hasil dari penghayatan seseorang terhadap sesuatu hal yang menimbulkan kesan positif seperti senang, bahagia, baik, bagus, benar dan lain sebagainya. Nilai dapat diperoleh dari dua jalan, yaitu melalui otak dan fungsi akal (pemikiran) serta dari hati dan fungsi rasa atau perasaan (Maksudin: 2010). Nilai akan selalu berhubungan dengan kebaikan, kebajikan dan keluhuran budi serta akan menjadi sesuatu yang dihargai dan dijunjung tinggi serta dikejar oleh seseorang sehingga ia merasakan adanya suatu kepuasan, dan ia merasa menjadi manusia yang sebenarnya (Sutarjo Adisusilo:2013).

Secara garis besar nilai dibagi menjadi dua kelompok, yaitu nilai-nilai nurani dan nilai-nilai memberi. Nilai nurani adalah nilai yang ada pada diri manusia kemudian berkembang menjadi perilaku dan cara kita memandang orang lain. Yang termasuk dalam nilai nurani adalah kejujuran, keberanian, cinta damai, keandalan diri, potensi, disiplin, tahu batas, kemurnian dan kesesuaian. Sedangkan nilai memberi menurut 
Zaim El Mubarok yang dikutip oleh Qiqi Yuliati dan Rusdiana adalah nilai yang harus dipraktekkan atau dibagi. Yang akhirnya akan diterima sebanyak yang dibagikan. Diantaranya adalah setia, dapat dipercaya, hormat, cinta, kasih, sayang, peka, tidak egois, baik hati, ramah, adil dan murah hati (Qiqi Yuliati Zakiyah dan Rusdiana:2014).

Karakter dalam KBBI berarti tabiat, sifat-sifat kejiwaan, akhlak atau budi pekerti yang membedakan seseorang dengan orang lain atau watak (KBBI:2008). Sedangkan menurut Simon Philips, karakter adalah kumpulan tata nilai yang menuju pada suatu sistem, yang melandasi suatu pemikiran, sikap, dan perilaku yang ditampilkan (Mansur Muslich: 2011). Sedangkan menurut Marzuki, karakter merupakan nilai-nilai perilaku manusia yang universal yang meliputi seluruh aktivitas manusia, baik dalam rangka berhubungan dengan Tuhannya, dengan dirinya, dengan sesamamanusia, maupun dengan lingkungannya, yang terwujud dalam pikiran, sikap, perasaan, perkataan, dan perbuatan berdasarkan norma-norma agama, hukum, tata karma, budya dan adat istiadat (Marzuki: 2009)

Sehingga dapat disimpulkan, bahwa karakter adalah sikap, sifat atau watak yang melandasi setiap perilaku seseorang dalam berhubungan atau berinteraksi dengan Tuhannya, sesama manusia, maupun dengan lingkungan. Karakter tidak dapat di ajarkan secara instan atau tiba-tiba, tetapi membutuhkan pembiasaanpembiasaan yang kontinyu. Pembiasaan-pembiasaan yang kontinyu tersebut tentunya harus didukung oleh semua pihak sehingga karakter yang melekat pada pribadi seseorang dapat menjadi kebiasaan.

Salah satu tujuan pendidikan di Indonesia adalah untuk mencetak manusia yang berkarakter. Karena manusia yang cerdas secara kognisi saja tidak cukup jika tidak di imbangi dengan karakter yang baik. Oleh karenanay, dalam kurikulum pendidikan baru di Indonesia, guru wajib memberikan pengajaran, dan pendidikan karakter dalam setiap pembelajaran.

Nilai-nilai dalam pendidikan karakter yang wajib diajarkan dalam pembelajaran menurut Kemendiknas adalah religious, jujur, toleransi, disisplin, kerja keras, kreatif, mandiri, demokratis, rasa ingin tahu, semangat kebangsaan, cinta tanah air, menghargai prestasi, bersahabat/komunikatif, cinta damai, gemar membaca, peduli lingungan, peduli sosial dan tanggung jawab (Suyadi: 2013).

Peduli lingkungan adalah sikap dan tindakan yang selalu berupaya mencegah kerusakan pada lingkungan alam disekitarnya, dan mengembangkan upaya-upaya untuk memperbaiki kerusakan alam yang sudah terjadi dan selalu ingin memberi 
bantuan bagi orang lain dan masyarakat yang membutuhkan (Muhammad Mustari:2014). Pemahaman yang mendasar dan baik tentang lingkungan sangat dibutuhkan karena dengan pemahaman tersebut manusia akan diantarkan kepada kesadaran akan kewajiban dan tanggung jawabnya terhadap lingkungan. Hal tersebut disebut juga dengan kepedulian lingkungan yang merupakan wujud sikap mental individu yang direfleksikan dalam dirinya (Syukri Hamzah: 2014).

Allah SWT telah banyak mengajarkan umatnya untuk menjadi pelaku aktif dalam mengolah lingkungan serta melestarikanya, seperti dalam surat Ar Rum ayat 9. Pesan yang terkandung dalam surat Ar Rum ayat 9 diatas menggambarkan agar manusia tidak mengeksploitasi sumber daya alam secara berlebihan yang dikhawatirkan terjadinya kerusakan serta kepunahan sumber daya alam, sehingga tidak memberikan sisa sedikitpun untuk generasi mendatang (Arif Sumantri:2010). AlQur'an juga mengajarkan kepada umatnya untuk selalu membiasakan diri bersikap ramah terhadap lingkungan seperti yang terkandung dalam surat Huud ayat 117 . Penjelasan surat Huud ayat 117 adanya kepedulian terhadap lingkungan memberikan dua pahala sekaligus, yakni pahala surga dunia berupa hidup bahagia dan sejahtera dalam lingkungan yang bersih, indah dan hijau dan pahala akhirat kelak (Muhammad Mustari: 2014). Al-Qur'an dengan jelas telah memerintahakan dan mengajarkan umat manusia yang ditunjuk sebagai pemimpin di bumi untuk berlaku positif dan aktif terhadap lingkungan dengan membiasakan diri untuk menjaga lingkunganya dengan melakukan kegiatan yang membangun dan tidak merusak alam serta bersikap aktif dengan melakukan kegiatan pelestarian alam.

Ada beberapa nilai karakter yang menunjukkan sikap peduli lingkungan (Ibrahim Abdul-Matin:2010) Diantaranya adalah:

1. Memahami kesatuan Yuhan dan Ciptaan-Nya. (Tauhid) Manusia berasal dari Allah, begitu pula alam semesta ini berserta segala sesuatu yang di dalamnya. Segala sesuatu yang berasal dari Allah akan kembali kepada Allah. Alam semesta dan segala isinya merupakan salah satu tanda kebesaran-Nya, yang merupakan wujud dari Ke-Esaan Allah. Oleh karena itu, wajib bagi umat manusia untuk mengikuti tanda-tanda kebesaranya dan mensyukuri segala ciptaan-Nya.

2. Melihat tanda-tanda Tuhan di mana saja. Jika di cermati, dalam AI-Qur'an telah banyak disebutkan mengenai frasa "tanda-tanda bagi kaum yang berfikir". Frasa tersebut banyak diulang-ulang dalam Al-Qur'an karena manusia cederung 
melupakan fakta tersebut. Alam semesta telah diciptakan dengan tanda-tanda kebesaran Allah didalamnya. Sehingga melakukan suatu perbuatan yang buruk terhadap alam berarti mengingkari kebesaran Tuhan. Karenanya, manusia perlu berusaha untuk melatih pikiran dan jiwa agar bisa menyerap dan memahami fakta bahwa segalas esuatu yang ada disekitar kita merupakan pesan atau tanda Ketuhanan.

3. Menjadi penjaga (khalifah) di bumi. Manusia diciptakan dari tanah, dan manusia merupakan wakil Allah di muka bumi. Manusia terlahir karena kasih sayang Allah, dan akan kembali kepada-Nya di usia yang telah ditentukan. Manusia sendirilah yang akan menentukan apakah dia akan meninggalkan dunia ini sebagai tempat yang lebih baik dari saat dia terlahir dan hidup didalamnya, atau sebaliknya. Khalifah Allah di muka bumi adalah orang yang mampu menjaga bumi dan menjadikanya tempat yang lebih baik.

4. Menjaga kepercayaan Tuhan (amanah). Sebagai Khalifah di muka bumi yang dilengkapi dengan kesempurnaan bentuk, akal dan hati, Allah telah menyertakan amanahnya kepada manusia untuk bertindak sebagai pelindung bumi. Allah memberikan kepercayaan untuk bertanggung jawab atas semua anugerah tersebut. Sebagian orang ada yang menerima tugasnya sebagai penjaga bumi, dan adapula yang menyalahgunakan perannya tersebut.

5. Berjuang menegakkan keadilan. Adil dalam konteks ini adalah dengan memanfaatkan alam dengan bijaksana, melakukan berbagai tindakan bukan karena desakan hasrat pribadi dan kepentingan material tetapi disdasari keyakinan bahwa setiap ciptaan Allah mempunyai hubungan dan keterkaitan satu sama lain. Jika manusia menyadari keterhubungan tersebut, maka manusia tidak akan melakukan tindakan yang merusak dan merugikan makhluk lain.

6. Hidup selaras dengan alam. Allah menciptakan segala sesuatu dalam keseimbangan yang sempurna. Allah menciptakan matahari dan bulan sebagai penanda bagi manusia untuk bekerja dan beristirahat. Allah telah menciptakan tumbuh-tumbuhan dan hewan sebagai teman, pelindung dan sumber makanan bagi manusia. Semuanya telah disusun sesuai dengan tugas masing-masing. Dengan demikian, kewajiban manusia hanyalah untuk hidup selaras, sesuai dengan alam supaya keseimbangan tersebut tidak rusak.

Adapun indikator yang menunjukkan sikap peduli lingkungan menurut Arif Sumantri (Arif Sumantri: 2010) adalah: 
1. Muhasabah (Evaluasi Diri). Sebagai perwujudan nyata dari bukti adanya koreksi dan evaluasi untuk menjadi lebih baik dalam pegelolaan lingkungan, manusia perlu memelihara, merawat, menjaga, melindungi, dan melestarikan lingkungan beserta seluruh isinya. Dalam artian manusia tidak boleh merusak dan menghancurkan lingkungan beserta seluruh isinya.

2. Murraqobah (Kedekatan pada Pencipta Alam) merupakan prinsip dimana setiap orang dituntut dan diwajibkan untuk memiliki kedekatan pada alam sebagai wujud kedekatan manusia pada penciptanya. Sehingga dengan memiliki sikap dekat kepada Tuhan, manusia dapat bertanggung jawab dan menghormati alam yang telah dianugerahkan Tuhan kepada umatya.

3. Muahhadah (Kesatuan), Allah menciptakan manusia dengan berbagai macam agama dan suku adalah dengan tujuan supaya manusia memiliki rasa saling membutuhkan antara satu sama lain. Nilai-nilai muahaddah (kesatuan) lingkungan akan mendorong manusia untuk mengambil kebijakan yang proalam, pro-lingkungan, atau menentang setiap sikap yang merusak alam. Muahhadah dalam lingkungan akan mendorong manusia untuk menentang dan mengingatkan setiap tindakan yang mengakibatkan musnahnya spesies tertentu atau rusaknya ekosistem.

4. Muaqobah (Hukuman), Prinsip muaqobah menekankan pada nilai, kualitas, cara hidup yang baik serta mutu kehidupan yang lebih mulia dihadapan sang pencipta alam semesta. Prinsip muaqobah menjadi penting karena krisis ekologi yang terjadi karena pola pikir manusia yang berpusat pada diri sendiri, memandang alam sebagai objek pemuas kebutuhan hidup serta pola hidup manusia modern yang konsumtif.

5. Mujahadah (Perjuangan atau Ikhtiar)

Prinsip mujahadah adalah prinsip dimana manusia harus berperilaku saling berkaitan antara manusia maupun alam semesta dengan diatur oleh tatanan sosial. Prinsip ini menuntut manusia agar dapat melakukan ikhtiar atau perjuangan dalam pengelolaan lingkungan.

Setiap manusia merupakan pemimpin yang diberikan amanah untuk menjaga lingkungan. sehingga setiap yang ada dibumi merupakan tanggung jawab manusia untuk mengelola dan memanfaatkannya sesuai dengan proporsi.

Pendidikan Agama Islam (PAI) di Madrasah merupakan suatu rumpun mata pelajaran agama yang saling terikat satu sama lain. Adapun mata pelajaran dalam 
rumpun PAI yang diajarkan di madrasah adalah Fiqh, Aqidah Akhlak, Al Qur'an Hadis dan SKI. Pembelajaran PAI memiliki peran umum dalam implementasi karakter peduli lingkungan. Sikap peduli lingkungan yang diajarkan dalam pembelajaran PAI yang pertama adalah Memahami ke-Esaan Tuhan dan Ciptaan-Nya (Tauhid). Dalam pelajaran Al Qur'an hadis diajarkan beberapa ayat yang berhubungan dengan peduli lingkungan, yaitu Q.S. Ar-Rum: 41-42 yang merupakan materi dari Kompetensi dasar ke 2, yaitu mahami ayat-ayat Al-Qur'an tentang perintah menjaga kelestarian lingkungan hidup.

Adapun dalam pelajaran Fiqh, diajarkan lewat materi tentang mencuri, menyamun dan merampok yang diintegrasikan dengan PLH dan merupakan materi dari standar kompetensi tentang mengenalkan, memahami dan mengimplementasikan ilmu fiqih di dalam kehidupan sehari-hari (terintegrasi Pendidikan Lingkungan Hidup). Dalam pelajaran Aqidah Akhlak, materi mengenai peduli lingkungan diajarkan dalam materi ishraf, tabdzir, dan fitnah yang diintegrasikan dengan PLH dan merupakan materi ajar dari Standar kompetensi tentang memahami tasawuf.

Kedua adalah Melihat tanda-tanda Tuhan di mana saja, Salah satu tanda-tanda Tuhan adalah kasih sayang. Kasih sayang dan kepedulian adalah prinsip moral satu arah, menuju yang lain, tanpa mengharapkan balasan. Siswa diajarkan untuk menjadi pribadi yang peka terhadap lingkungan dengan meawat taman sekolah serta lingkungan sekolah. Pengajaran karakter tersebut muncul dalam pembiasaan bertindak langsung merawat lingkungan hidupnya yang menimbulkan rasa sayang dan memiliki sehingga siswa dapat memunculkan rasa kepedulian lingkungan dalam dirinya, dan dapat diaplikasikan di lingkungan sekolah maupun di lingkungan luar sekolah.

Ketiga adalah menjadi penjaga (khalifah) di bumi. Lewat pembelajaran AlQur'an Hadis, siswa diajarkan untuk menjaga lingkungan hidup melalui materi menjaga kelestarian lingkungan hidup yang terdapat dalam surat Ar Rum ayat 41-42. Dalam silabus AI-Qur'an hadis nilai karakter yang diajarkan adalah tanggung jawab, membuang sampah pada tempatnya, peduli lingkungan, sehat kelas dan sehat madrasah. Nilai karakter yang ingin diajaran tercantum dalam kegiatan pembelajaran dengan mengidentifikasi kerusakan alam akibat ulah tangan manusia yang terjadi di dunia. Kegiatan pembelajaran tersebut terealisasi dengan diskusi dalam kelas dan pemberian tugas pembiasaan yang harus dilakukan dikerjakan di lingkungan sekolah 
dan luar lingkungan sekolah. Salah satu tugas yangharus dilaksaakan adalah dengan memilah sampah organic dan sampah an organik.

Keempat Menjaga kepercayaan Tuhan (amanah). Dalam pembelajaran Fiqh, guru menjelaskan kepada siswa sikap tanggung jawab terhadap keamanan serta kenyamanan lingkungan sekolah maupun lingkungan diluar sekolah. Karena menjaga lingkungan merupakan tugas bersama setiap elemen masyarakat yang tinggal didalamnya. Dalam silabus figh kelas XI terintegrasi PLH (Pendidikan Lingkungan Hidup), nilai karakter peduli lingkungan yang ditunjukkan adalah menjaga lingkungan. sehingga diharapkan siswa dapat memahami bahwa perilaku mencuri, menyamun dan merampok dalam skala besar yang merugikan Negara dan lingkungan hidup merupakan sikap yang harus dihindari. Materi yang diajarkan adalah mencuri, menyamun dan merampok. Adapun ayat Al-Qur'an yang melarang perilaku mencuri, menyamun atau merampok adalah surat Al-Baqarah ayat 188.

Dalam pelajaran Al-Qur'an Hadis materi tentang menjaga lingkungan hidup yang terdapat dalam Q.S Ar-Rum: 41-42 menjelaskan bahwa kerusakan yang terjadi di muka bumi ini adalah perbuatan manusia. Adapun pada pembelajaran Al-Qur'an dan Hadis, guru mengembangkan RPP pelestarian lingkungan hidup dengan metode tanya jawab, diskusi, penugasan, kerja kelompok, dan refleksi. Refleksi dilaksanakan pada akhir pembelajaran, siswa diajak untuk menyebutkan hikmah dari pelajaran mengenai pelestarian lingkungan hidup. Setelah menyebutkan hikmah, siswa diminta untuk merenungkan apa saja akibat buruk dari sikap merusak lingkungan. Metode refleksi ini diharapkan dapat membantu siswa untu mengembangkan sikap hormat terhadap alam, dan dapat memberikan kesan pada memori siswa.

Kelima adalah Berjuang menegakkan keadilan. Adil terhadap lingkungan dalam pembelajaran PAI di MAN Yogyakarta II diajarkan lewat pelajaran aqidah akhlak dalam materi adil. Pengertian adil dalam buku panduan belajar aqidah Akhlak adalah meletakkan sesuatu pada tempatnya, mmberikan atau menerima sesuatu sesuai dengan haknya. Dalam prakteknya, MAN Yogyakarta mengajarkan membiasakan siswa untuk bersikap adil dengan menghemat penggunaan air dan penggunaan listrik. Dengan diajarkanya menghemat pengguaan air dan listrik, diharapkan siswa dapat memiliki sikap adil dalam kesehariannya. Sehingga siswa dapat memiliki kebiasaan tersebut diluar lingkungan sekolah.

Sikap adil diajarkan dalam pelajaran Al-Qur'an Hadis materi tentang memahami ayat-ayat Al-Qur'an tentang manusia dan tugasnya sebagai hamba Allah 
dan kholifah di bumi. Guru menekankan kepada siswa bahwa sebagai wakil Allah di bumi manusia harus berlaku adil dalam menjaga keseimbangan lingkungan.

Keenam adalah Hidup selaras dengan alam. Prinsip yang ditekankan dari hidup selaras dengan alam adalah hidup sederhana dengan mempertimbagkan nilai, kualitas, cara hidup yang baik, dan bukan kekayaan, sarana, standar material sehingga dapat memiliki mutu hidup yang baik. Dalam pembelajaran figh Bab Tabdzir, siswa diajarkan untuk hidup sederhana dengan tidak menghambur-hamburkan apa yang dimilikinya. Seperti apakah sikap tabdzir, cara agar tidak boros dan solusi terhadap akibat ulah manusia yang ingin hidup mewah, serta bagaimana memanfaatkan barang-barang yang masih bisa digunakan.

Dalam pembelajaran Fiqh mengenai bab Tabdzir yang diintegrasikan dengan Pendidikan Lingkungan Hidup (PLH), siswa diajak untuk berdiskusi mengenai contoh tabdzir, akibat dariperbuatan tabdzir terhadap lingkungan dan cara agar manusia dapat menghindai sikap tabdzir. Adapun kesimpulan dari hasil diskusi siswa yaitu sikap tabdzir merupakan perbuatan yang merugikan diri sendiri maupun orang lain. Kaitannya dengan PLH adalah bahwa sikap tabdzir dapat merusak lingkungan.

Dalam prakteknya, implementasi sikap peduli lingkungan dalam pembelajaran PAI tidak akan berhasil jika tidak ada faktor-faktor yng mendukung. Beberapa faktor pendukung dari implementasi karakter peduli lingkungan adalah (1) Visi dan Misi MAN Yogyakarta II. Visi dan misi madrasah telah mencantumkan nilai peduli lingkungan secara tersirat maupun tersurat. Sehingga dalam pelaksanaan program belajar mengajar maupun kegiatan lainnya selalu menggunakan Visi dan Misi sebagai acuan semua kebijakan kepala madrasah dan semua kegiatan madrasah madrasah.

Adapun Visi yang tersirat adalah dengan pembiasaan akhlakul karimah yang diajarkan lewat pembelajaran PAI di kelas dan melalui pemberian contoh dari guru serta semua stakeholder. Sedangkan secara tersurat dijelaskan lewat misi, tujuan MAN Yogyakarta II, RPP dan silabus. (2) ApeL (Agen peduli Lingkungan). Yaitu sebuah organisasi yang dibuat oleh sekolah untuk siswa yang memiliki minat dan komitmen yang kuat dalam bidang lingkungan. Program ApeL yang digalakkan adalah bank sampah. Bank sampah merupakan program MAN Yogyakarta II yang di gagas oleh pihak sekolah untuk menampung atau memanfaatkan sampah. Tidak hanya siswa saja yang bisa menbung sampah, akan tetapi semua guru dan karyawan bisa menbung di bank sampah. Setiap warga sekolah yang menabung sampah akan memiliki rekening sampah. Siswa yang menabung di bank sampah akan diberikan 
uang untuk kas kelas dan bagi guru dan karyawan akan diganti dengan minyak goreng atau keperluan rumah tangga jika tabungan sampah sudah mencukupi.

Adanya APeL ini membantu siswa untuk membiasakan supaya tidak membuang sampah sembarangan dan juga supaya siswa dapat memahami jenisjenis sampah, sehingga pengetahuan mengenai jenis-jenis sampah dapat membantu siswa untuk memanfaatkan barang bekas agar memiliki nilai manfaat bagi diri sendiri maupun lingkungan. (3) Reward and punishment merupakan salah satu faktor pendukung yang efektif untuk membiasakan siswa memiliki sikap peduli terhadap lingkungan. Reward dan punishment di MAN Yogyakarta sebagian besar dikaitkan dengan program Adiwiyata sekolah yang diharapkan dapat membantu membentuk sikap siswa supaya peduli terhadap lingkungan.

Reward biasanya berupa penghargaan dengan menjadi pengurus atau pelopor peduli lingkungan di sekolah, sehingga potensi peduli lingkungan yang dimiliki siswa memiliki tempat untuk berkembang. Dan punishment yang diberikan adalah seperti membawa tanaman untuk sekolah, menyirami tanaman selama satu minggu serta menjadi petugas Bank Sampah selama 3 hari. (4) Lomba. Lomba yang bertema lingkungan juga menjadi faktor pendukung keberhasilan implementasi nilai peduli lingkungan. Adapun peserta yang dipilih untuk mewakili sekolah dalam lomba adalah siswa yang menjadi kader lingkungan hidup di MAN Yogyakarta II. Dengan mengikuti lomba siswa memiliki jaringan yang lebih luas dengan komunitas diluar sekolah. Sehingga siswa memiliki kesempatan da memiliki wadah untuk mengembangkan sikappeduli lingkunganya dan siswa memiliki teman yang satu tujuan.

Siswa yang mengikuti lomba yang bertemakan lingkungan hidup juga akan menjadi kader pelopor peduli lingkungan di sekolah dengan mengajak teman-teman yang lain untuk masuk ke komunitas tersebut sehingga ilmu yangdidapatkan dapat diajarkan kepada teman yang tidak termasuk dalam komunitas tersebut. (6) Kegiatan Ekstrakurikuler. MAN Yogyakarta II memiliki kegiatan ekstrakulikuler Pecinta Alam MAN Yogyakarta II (PAMANDAYA) yang betujuan untuk membentuk karakter yang rasa cinta tanah air, tanggung jawab dan cinta lingkungan.

Kegiatan ekstrakurikuler PAMANDAYA mengajarkan siswa supaya memiliki jiwa yang kuat, rasa kekeluargaan yang tinggi sehingga memiliki jiwa sosial yang tinggi serta memiliki kepekaan yang tinggi terhadap lingkungan. pamandaya jugamembeika motivasi kepada anggotanya dengan tujuan membagun kreatifitas serta menjadikan siswa menjadi lebih baik. Ada tiga hal yang ditekankan dalam ekstra pamandaya ini, 
yaitu tentang pembelajaran secara benardan baik dalam bernegoisasi, tetang safety prosedur dalam petualangan alam bebas dan tetan kekeluargaan mendalam yang terjalin dalam anggota siswa pecinta alam MAN Yogyakarta II.

Selain faktor pendukung, tenntusaja madrasah menemukan beberapa faktor penghambat dalam pelaksanaan implementasi karakter peduli ligkungan. Beberapa faktor penghambat tersebut yang pertama adalah perbedaan parakter siswa. Kedua, waktu yang terbatas hanya di jam sekolah, yaitu pukul 07.00 sampai dengan pukul 15.00. Ketiga, kurangnya pengawasan di luar sekolah.

\section{SIMPULAN}

Berdasarkan pada pemaparan hasil penelitian yang telah disampaikan pada bab sebelumnya, maka dapat diambil kesimpulan bahwa: 1) Pembelajaran PAI di MAN Yogyakarta II telah menerapkan nilai peduli lingkungan yang meliputi enam prinsip peduli lingkungan yaitu: a) memahami ke-Esaan Tuhan, b) melihat tanda-tanda Tuha di mana saja, c) menjadi penjaga (khalifah) di bumi, d) mejaga kepercayaan Tuhan, e) berjuang menegakka keadilan, f) menjalani kehidupan yang seimag dengan alam.

2) Ada beberapa faktor penghambat dan pendukung implementasi ilai peduli lingkungan di MAN Yogyakarta II. Adapun faktor penghambatnya adalah: a) waktu yang relative pendek, b) perbedaan karakter siswa, c) kurangnya pegawasa diluar sekolah. Sedangkan faktor pendukungnya adalah: a) visi dan misi madrasah, b) APeL (Agen Peduli Lingkungan), c) Reward and Punishment, d) lomba, dan e) kegiatan ekstrakurikuler.

Hasil dari pembiasaan nilai kepedulian lingkungan di MAN Yogyakarta II adalah bahwa semua nilai kepedulian lingkungan akan masuk pada diri peserta didik dan akan menjadi nilai karakter apabila diajarkan secara terus menerus dan dikerjakan bersama-sama secara serentak dengan semua warga sekolah dan keluarga. Peran PAI dalam penerapan nilai peduli lingkungan juga sangat berpengaruh terhadap cara berfikir da cara bersikap siswa di kehidupan sehari-hari diluar maupun didalam lingkungan sekolah.

\section{DAFTAR PUSTAKA}

Abdul-Matin, Ibrahim, Greendeen Inspirasi Islam dalam Menjaga dan Mengelola Alam, Jakakarta: Zaman, 2010. 
Haidi Hajar, Relasi Alam dan Agama (Sebuah Upaya Penyelarasan antara Budaya Mistis dengan Pelestarian Lingkungan), Yogyakarta: Jurnal Esensia jurnal ilmu hukum Ushuluddin Vol. XIII No. 2, Juli 2012.

Maksudin, Pendidikan Nilai Komprehensif Teori dan Praktik, Yogyakarta: UNY Press, 2009.

Marzuki, Prinsip Dasar Akhlak Mulia: Pengantar Studi Konsep-Konsep Dasar Etika dalam Islam, Yogyakarta: Debut Wahana Press-FISE UNY, 2009)

Muchlis, Mansur, Pendidikan KArakter Menjawab Tantangan Krisisi Multidimensional, Jakarta: Bumi Aksara, 2012

Nasution, S. Metode Research (Penelitian IImiah), Jakarta: PT Bumi Aksara, 2006.

Nawawi, Hadari Metode Penelitian Bidang Sosial, Yogyakarta: Gajah Mada University Press, 2007.

Pusat Bahasa Departemen Pendidikan nasional, Kamus Besar Bahasa Indonesia, Jakarta: Gramedia, 2008

Shihab, Quraish Tafsir Al Misbah (Pesan, Kesan dan Keserasian Al-Qur'an) Volume 5, Jakarta: Lentera Hati, 2004.

Suyadi. Strategi Pembelajaran Pendidikan Karakter, Bandung: Remaja Rosdakarya, 2013)

Syaodih, Nana. Metode Penelitian Pendidikan, Bandung: PT Remaja Rosdakarya, 2010.

Zakiyah, Qiqi Yuliati dan Rusdiana. Pendidikan Nilai (Kajian Teori dan Praktik di Sekolah), Bandung: Pustaka Setia, 2014 